\section{NEISSERIA SUBFLAVA PERITONITIS: CASE REPORT}

\author{
Peritonite por Neisseria subflava: relato de caso
}

Changhua CHEN'1, Ping-Fang CHIU', Jen-ShiouLIN ${ }^{1}$

From the ${ }^{1}$ Changhua Christian Hospital, Department of Internal Medicine, Changhua, Taiwan DESCRITORES - Peritonite. Falha de tratamento. Infecções relacionadas a cateter

\author{
Correspondence: \\ Changhua Chen \\ E-mail: \\ chenchanghuachad@gmail.com; \\ changhua@cch.org.tw
}

Financial source:Partially supported by a grant from the Changhua Christian Hospital (grant 105-CCH-IPR-001) Conflicts of interest: none Received for publication: 04/04/2016 Accepted for publication: 07/03/2017
HEADINGS - Peritonitis. Treatment failure. Catheter-related infections

We disclose three important issues on CAPD-associated $N$. subflava peritonitis. First is the timing for the removal of the peritoneal dialysis catheter and reinsertion of a new catheter. The ISPD recommends at least five days after appropriate antibiotics and failure of cleaning the CAPD effluent (1C) 1 , and a minimum interval of $2-3$ weeks between catheter removal and reinsertion of a new catheter ${ }^{1}$. The second is the administration duration of effective antibiotics. The ISPD recommends that non-Pseudomonas gram-negative peritonitis be treated with effective antibiotics for at least three weeks (2C)1, in contrast to two weeks as recommended by the Infectious Diseases Society of America ${ }^{2}$. The third is the source of infection. The present case might be due to touch contamination, exit-site infection, or possibly a dental source from periodontal disease or an oropharyngeal source ${ }^{3}-4$. Considering the occurrence of CAPD-associated peritonitis, the patient's aseptic technique and home circumstances should be reviewed. In addition, potential problems were identified in the patient's hand-washing technique and lack of face mask use. Although $N$. subflava peritonitis is rarely reported, we emphasize that compliance for the aseptic technique and standard procedure is critical in CAPD patient care.

\section{REFERENCES}

1. Li PK, Szeto CC, Piraino B, de Arteaga J, Fan S, Figueiredo AE, Fish DN, Goffin E, Kim YL, Salzer W, Struijk DG, Teitelbaum I, Johnson DW. ISPD Peritonitis Recommendations: 2016 Update on Prevention and Treatment. Perit Dial Int. 2016;36(5): 481-508.

2. Mermel LA, Allon M, Bouza E, Craven DE, Flynn P, O'Grady NP, Raad II, Rijnders BJ, Sherertz RJ, Warren DK. Clinical practice guidelines for the diagnosis and management of intravascular catheter-related infection: 2009 Update by the Infectious Diseases Society of America. Clin Infect Dis 2009;49(1): 1-45.

3. Liu G, Tang CM, Exley RM. Non-pathogenic Neisseria: members of an abundant, multi-habitat, diversegenus. Microbiology2015;161(7):12971312.

A 74-year-old man who had had uremia since 2010 and was receiving maintenance CAPD was admitted because of fever, nausea, vomiting, diffuse abdominal pain, and opaque dialysis effluent one day prior to admission. On admission, no rebound tenderness was observed. His serum white blood cell count was $7.000 / \mu \mathrm{l}$ and serum creatinine level was $14.49 \mathrm{mg} / \mathrm{dl}$. Abdominal plain radiography showed no evidence of ileus or bowel obstruction. N. subflava from dialysate was identified on matrix-assisted laser desorption ionization-time of flight mass spectrometry (bioMerieux, Hazlewood, Mo.). A susceptibility test for $N$. subflava was performed by using the bioMérieux VITEK 2 system (bioMerieux, VITEK 2 system, Hazlewood, Mo.). The minimum inhibitory concentration of ceftriaxone was $0.094 \mu \mathrm{g} /$ $\mathrm{ml}$ by Etest (AB Biodisk, Sweden). His blood cultures returned negative results for any pathogens. The patient experienced a brief improvement in symptoms, followed by symptom recurrence. Subsequent evaluation of the effluent showed a persistent elevation of the white blood cell count from 6624/ $\mu \mathrm{l}$ to $1890 / \mu \mathrm{l}$ in three days. His condition was compatible with refractory peritonitis according to the recommendations by the International Society Peritoneal Dialysis Peritonitis (ISPD) ${ }^{1}$. The peritoneal dialysis catheter was removed on admission day 7 . Thereafter, he received hemodialysis three times per week. Intravenous ceftiaxone at 2000 mg daily was prescribed for 21 days. He was discharged on admission day 22 with a stable clinical condition.
4. Warinner C, Rodrigues JF, Vyas R, Trachsel C, Shved N, Grossmann J Radini A, Hancock Y, Tito RY, Fiddyment S, Speller C, Hendy J, Charlton S, Luder HU, Salazar-García DC, Eppler E, Seiler R, Hansen LH, Castruita JA, Barkow-Oesterreicher S, Teoh KY, Kelstrup CD, Olsen JV, Nanni P, Kawai T, Willerslev E, von Mering C, Lewis CM Jr, Collins MJ, Gilbert MT, Rühli F, Cappellini E. Pathogens and host immunity in the ancient human oral cavity. Nature genetics 2014;46(4): 336-344. 